\title{
Effect of cutting parameters on surface roughness in turning of annealed AISI-1020 steel
}

\author{
Efecto de los parámetros de corte del torneado en la rugosidad \\ superficial de acero AISI- 1020 recocido
}

\section{Efeito dos parâmetros de corte do torneado na rugosidade superficial de aço AISI- 1020 recozido}

Fecha de recepción: 1 de octubre de 2017

Fecha de aprobación: 26 de diciembre de 2017

\author{
Omar Zurita* \\ Verónica Di-Graci* \\ María Capace ${ }^{*+*}$
}

\section{Abstract}

This study focuses on the effects of cutting parameters such as cutting speed $(V c)$, feed rate $(f)$, and depth of cut $(d)$ on roughness induced on the surface of annealed AISI 1020 steel when machined by turning using carbide insert tools. The results indicated that surface roughness increased when feed rate increased and cutting speed decreased. Depth of cut slightly influenced roughness. Analysis of variance and multiple regression techniques were used to formulate a quantitative equation for estimating predicted values of roughness as functions of the cutting parameters. The results showed that cutting speed is the most influencing parameter on surface roughness $(69.35 \%)$, followed by feed rate $(30.13 \%)$, while depth of cut failed to affect the responses substantially $(0.52 \%)$. The proposed model can be used to select the optimum parameters for minimum surface roughness in metal turning.

Keywords: AISI 1020; ANOVA; cutting speed; depth of cut; feed rate; surface roughness; turning.

\section{Resumen}

En este trabajo se estudian los efectos de los parámetros de corte: velocidad de corte $(V c)$, velocidad de avance $(f)$ y profundidad de corte $(d)$ en la rugosidad inducida en la superficie de acero AISI 1020 recocido torneado, empleando herramientas de insertos de carburo. Se encontró, a partir de los resultados obtenidos, que la rugosidad de la superficie aumentó, con velocidades de avance cada vez mayores y velocidades de corte decrecientes. Se encontró una ligera influencia de la rugosidad de la profundidad de corte. Análisis de la varianza (ANOVA) y múltiples técnicas de regresión se utilizaron para formular una ecuación cuantitativa para la estimación de valores de rugosidad en función de los parámetros de corte. Los resultados mostraron que la velocidad de corte es el parámetro que más influye en la rugosidad de la superficie $(69,35 \%)$, la velocidad de avance está en segundo $(30,13 \%)$, mientras que la profundidad de corte no afectó sustancialmente $(0,52 \%)$. El modelo propuesto puede

* M. Sc. Universidad Simón Bolívar (Caracas, Venezuela). ozurita@usb.ve.

** M. Sc. Universidad Simón Bolívar (Caracas, Venezuela).vdigraci@usb.ve.

*** M. Sc. Universidad Simón Bolívar (Caracas, Venezuela). mccapace@usb.ve. 
ser utilizado para seleccionar los parámetros óptimos para la obtención de rugosidad superficial mínima en el torneado de metales.

Palabras clave: AISI 1020, ANOVA, velocidad de corte, profundidad de corte, velocidad de avance, rugosidad superficial, torneado.

\section{Resumo}

Neste trabalho estudam-se os efeitos dos parâmetros de corte: velocidade de corte (Vc), velocidade de avanço (f) e profundidade de corte (d) na rugosidade induzida na superfície de aço AISI 1020 recozido torneado, empregando ferramentas de insertos de carburo. Encontrou-se, a partir dos resultados obtidos, que a rugosidade da superfície aumentou, com velocidades de avanço cada vez maiores e velocidades de corte decrescentes. Encontrou-se uma ligeira influência da rugosidade da profundidade de corte. Análise da variância (ANOVA) e múltiplas técnicas de regressão foram utilizadas para formular uma equação quantitativa para a estimação de valores de rugosidade em função dos parâmetros de corte. Os resultados mostraram que a velocidade de corte é o parâmetro que mais influi na rugosidade da superfície $(69,35 \%)$, a velocidade de avanço está em segundo $(30,13 \%)$, enquanto que a profundidade de corte não afetou substancialmente $(0,52 \%)$. O modelo proposto pode ser utilizado para selecionar os parâmetros ótimos para a obtenção de rugosidade superficial mínima no torneado de metais.

Palavras chave: AISI 1020, ANOVA, velocidade de corte, profundidade de corte, velocidade de avanço, rugosidade superficial, torneado.

\section{Para citar este artículo:}

O. Zurita, V. Di-Graci, and M. Capace, "Effect of cutting parameters on surface roughness in turning of annealed AISI-1020 steel," Revista Facultad de Ingeniería, vol. 27 (47), pp. 111-118, Jan. 2018. 


\section{INTRODUCTION}

AISI 1020 steel is characterized by a combination of high ductility and good strength, as well as by its ability to be easily machined. Due to these properties, it is often used in a variety of engineering applications, which include but are not limited to axles and automotive parts such as cams manufactured by machining.

Turning is a single-point cutting process in which a tool is used to remove material from a rotating cylindrical workpiece. After the machining process, the resulting surface roughness is important due to its role in evaluating the quality of the manufactured component. Irregularities in the workpiece surface, which may form sites for nucleation of corrosion and cracks, can affect its performance. Therefore, selecting optimized cutting parameters is fundamental to achieve the required surface quality.

The effects of turning parameters on the surface roughness were investigated by several authors on different materials: duplex stainless steels [1], AISI 304 stainless steel [2], AISI 1050 steel [3], nickel based Hastelloy [4], red brass [5], and aluminum 6061 [6]. These studies included a variety of experimental values of cutting parameters, but all the processes were carried out in dry conditions. However, recent analyses of the effect of coolant showed that lower surface roughness was achieved on components machined with coolant, as compared to those without a supply of coolant [6, 7]; they also reported an improvement in the machinability characteristics of the workpieces.

Further studies are still required to clarify the effect of cutting conditions on surface roughness; moreover, few results have been reported on the optimization of turning process parameters on AISI 1020 steel. Therefore, this work aimed at providing a better understanding of the influence of cutting parameters such as cutting speed $(V c)$, feed rate $(f)$, and depth of cut $(d)$ on the surface roughness induced in annealed AISI 1020 steel, when machined by turning using carbide insert tools. The intent was to develop a regression model useful for predicting an optimal surface finish.

\section{EXPERIMENTAL PROCEDURE}

In this investigation, the material used was a round bar of commercial AISI 1020 steel $(0.18 \pm 0.01 \% \mathrm{C}, 0.035$ $\pm 0.001 \% \mathrm{~S}$, and $0.40 \pm 0.01 \% \mathrm{Mn})$, cut in cylinders of $31.75 \mathrm{~mm}$ in diameter and $170 \mathrm{~mm}$ in length. The samples were annealed at $910{ }^{\circ} \mathrm{C}$ for one $\mathrm{h}$, followed by slowly cooling inside the furnace, thus achieving a homogenized microstructure.

The work specimens were turned with a cut fixed length of $100 \mathrm{~mm}$ in a numerically controlled lathe; all tests were carried out with ISO code DCMT 11T308MU carbide inserts and abundant quantity of water-soluble oil as coolant. A new insert's edge was used for each experiment, to guarantee equal cutting conditions and ensure the absence of changes in the surface properties of the material due to tool wear $[8,9]$.

The experiments were designed using a technique of variables [10]. Three levels were considered for feed rate, three levels of depth of cut, and two levels for cutting speed, for a total of 18 combinations, with two repetitions each run. The maximum and minimum limits (Table 1) were selected based on previous researches with similar steel [11] and restrictions by the lathe.

TABLE 1

PARAMETERS USED IN THE TURNING OF THE SAMPLES

\begin{tabular}{|c|c|c|}
\hline $\begin{array}{c}d \\
(\mathrm{~mm})\end{array}$ & $\begin{array}{c}f \\
(\mathrm{~mm} / \mathrm{rev}) \\
\end{array}$ & $\begin{array}{c}V c \\
(\mathrm{~m} / \mathrm{min}) \\
\end{array}$ \\
\hline 1 & 0.05 & 20 \\
\hline 2 & 0.15 & - \\
\hline 3 & 0.25 & 70 \\
\hline
\end{tabular}

After turning, the roughness of the machined surface (Ra) was measured using a Mitutoyo, Surftest 211 Profilometer by positioning the instrument perpendicular to the feed marks. Four measurements at randomly chosen locations of the surface were made for each sample to calculate the average value of $\mathrm{Ra}$. 
Then, the mean values of surface roughness for each combination of parameters were compared through the statistical Pareto-ANOVA, to identify the importance of each parameter and their percentage influence. In the analysis, the depth of cut $(d)$, feed rate $(f)$ and cutting speed $(V c)$ were the independent variables, while the surface roughness $(\mathrm{Ra})$ represented the dependent variable. The significance level was based on the P-value [12]:

Insignificant if $\mathrm{P}>0.10$

Mildly significant if $0.05<\mathrm{P}<0.10$

Significant if $\mathrm{P}<0.05$

Finally, a statistical mathematical expression was derived for the prediction of the surface roughness, using multiple linear regression methods [12].

\section{RESULTS AND DISCUSSION}

The depth of cut positively influenced surface roughness: roughness increased with increase in depth of cut (Fig. 1). This trend is because higher values of depth of cut produce more thrust force [13], which increases roughness due to a greater deformation of the chip that is more violently pushed against the machined surface, resulting in a worse surface finish. A very small increment in roughness with the depth of cut is indicated by the slopes of the curves, resulting in minimum and maximum differences values of $3 \%$ and $18 \%$, respectively, for fixed cutting speed and feed rate.

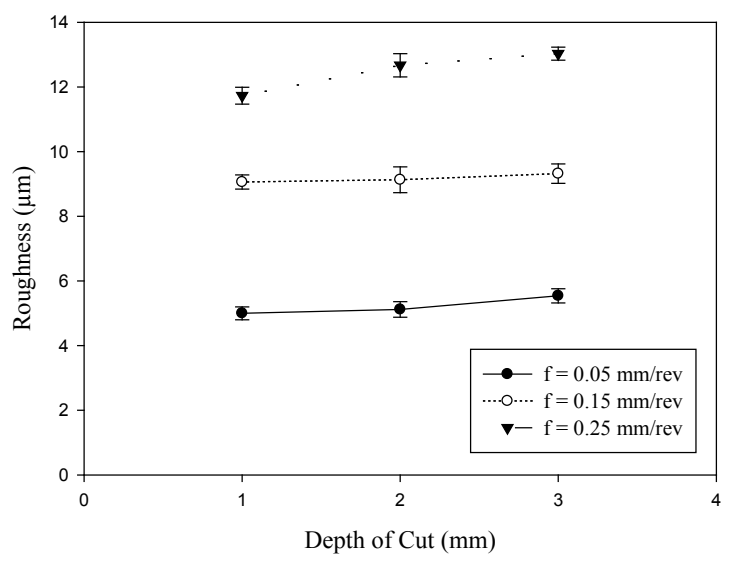

a)

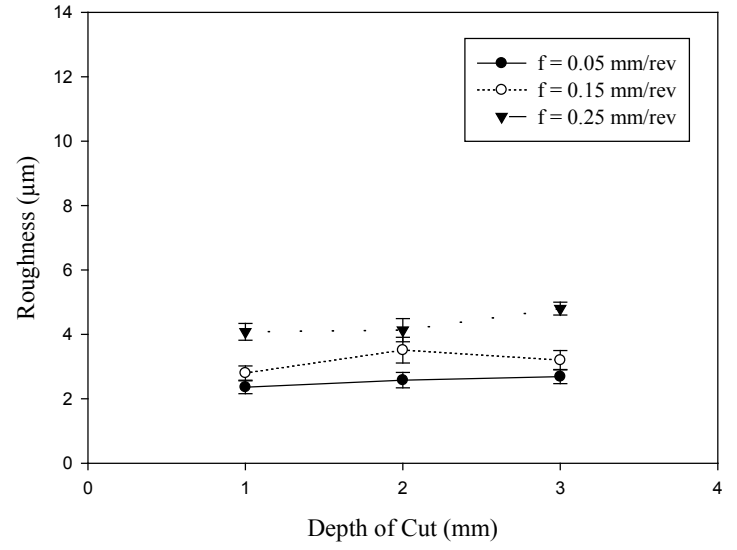

b)

Fig. 1. Roughness plotted against depth of cut for turned annealed AISI 1020 steel, with a cutting speed of (a) $20 \mathrm{~m} / \mathrm{min}$; and (b) $70 \mathrm{~m} / \mathrm{min}$.

Figure 2 shows the effect of feed rate on surface roughness. Similar to depth of cut, roughness raises constantly with feed rates, but in a much greater slope. This fact is related to the grooves left along the surface of the machined sample as the cutting tool moves, whereby with an increase in feed rate a greater separation between consecutive positions occurs. The experimental results showed that the roughness differences corresponding to a fixed cutting speed and depth of cut have values between $60 \%$ and $147 \%$.

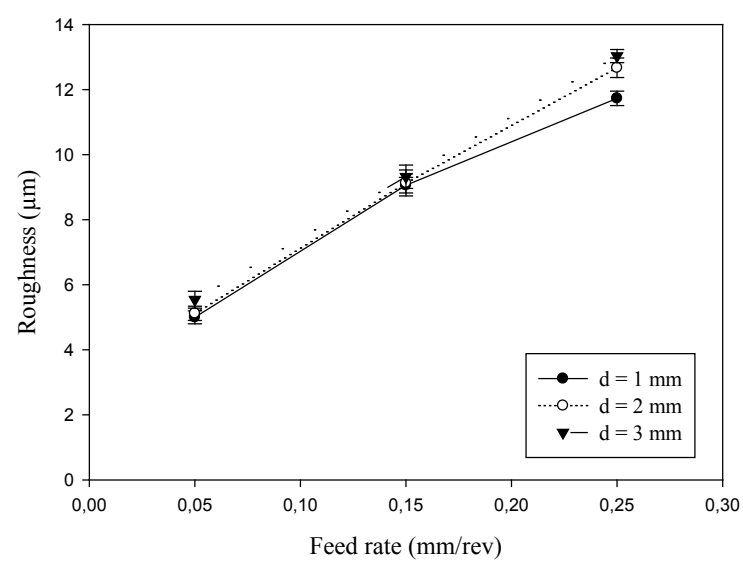

a) 


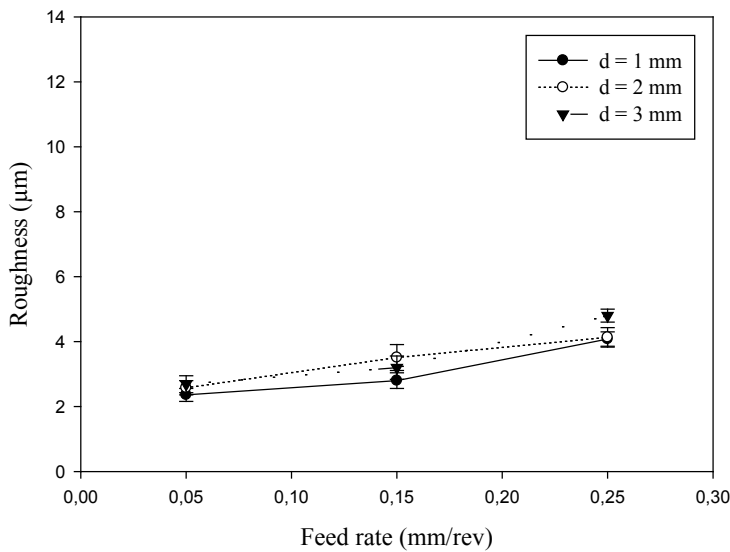

b)

Fig. 2. Roughness plotted against feed rate for the turned annealed AISI 1020 steel, with a cutting speed of (a) $20 \mathrm{~m} / \mathrm{min}$; and (b) $70 \mathrm{~m} / \mathrm{min}$.

Regarding the effect of cutting speed on surface roughness, the latter decreased with higher values of cutting speed (Fig. 3). The main reason for this can be that at higher cutting speeds the temperature increases because the material removal is more violent, producing the phenomenon of softening that improves the cutting process and thus diminishes superficial roughness [14]. Moreover, when the turning is performed at a low speed, a subsurface material fracture occurs, which contributes to increasing surface roughness; by increasing the cutting speed this effect disappears. The results showed differences in roughness for fixed feed rate and depth of cut, of $99 \%$ and $223 \%$, respectively.

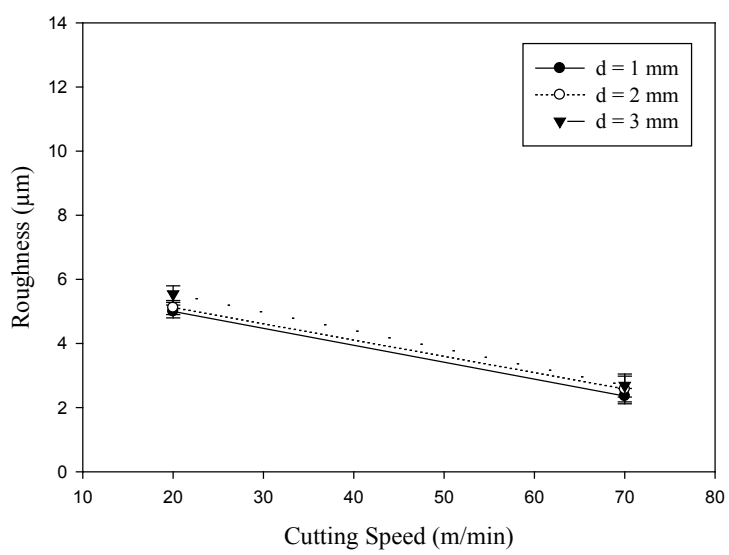

a)

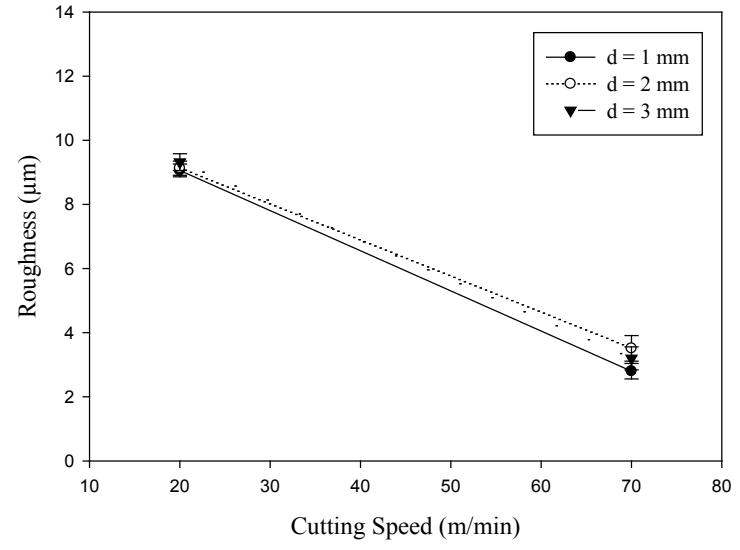

b)

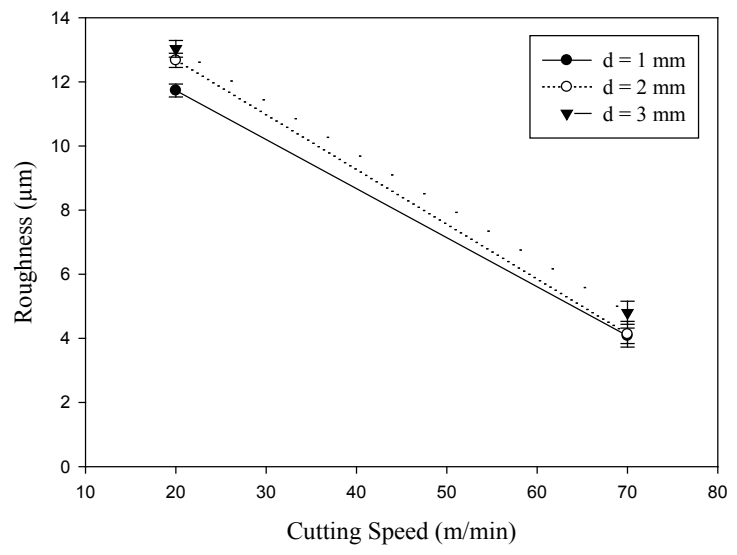

c)

Fig. 3. Roughness plotted against cutting speed for the turned annealed AISI 1020 steel, with a feed rate of (a) $0.05 \mathrm{~mm} / \mathrm{rev}$; (b) $0.15 \mathrm{~mm} / \mathrm{rev}$; and (c) 0.25 $\mathrm{mm} / \mathrm{rev}$.

The analysis of variance (ANOVA) performed on the experimental data is summarized in Table 2 ; the results confirmed that cutting speed $(V c)$ and feed rate $(f)$ are significant factors affecting the surface roughness ( $\mathrm{P}$ $<0.05)$, while depth of cut $(d)$ is mildly significant $(0.05<\mathrm{P}<0.10)$. This analysis was carried out for a confidence level of $95 \%$. 
TABLE 2

ANOVA FOR SURFACE ROUGHNESS

\begin{tabular}{cccccc}
\hline $\begin{array}{c}\text { Source of } \\
\text { variance }\end{array}$ & $\begin{array}{c}\text { Degrees of } \\
\text { freedom }\end{array}$ & Sum of squares & Mean squares & F - value & P - value \\
\hline Vc & 1 & 141.428 & 141.428 & 72.51 & 0.00 \\
f & 2 & 61.429 & 30.715 & 15.75 & 0.00 \\
d & 2 & 1.066 & 0.533 & 0.27 & 0.77 \\
Error & 12 & 23.407 & 1.951 & & \\
Total & 17 & 227.331 & & & \\
\hline
\end{tabular}

Figure 4 shows the percent contributions of each parameter on surface roughness. The length of each bar is proportional to the absolute value of its associated contribution or estimated effect. According to the performed Pareto chart, cutting speed was found to be the major factor affecting roughness values $(69.35 \%)$, whereas feed rate was found to be the second-ranking factor $(30.13 \%)$; the percent contribution of depth of cut plays a negligible role $(0.52 \%)$.

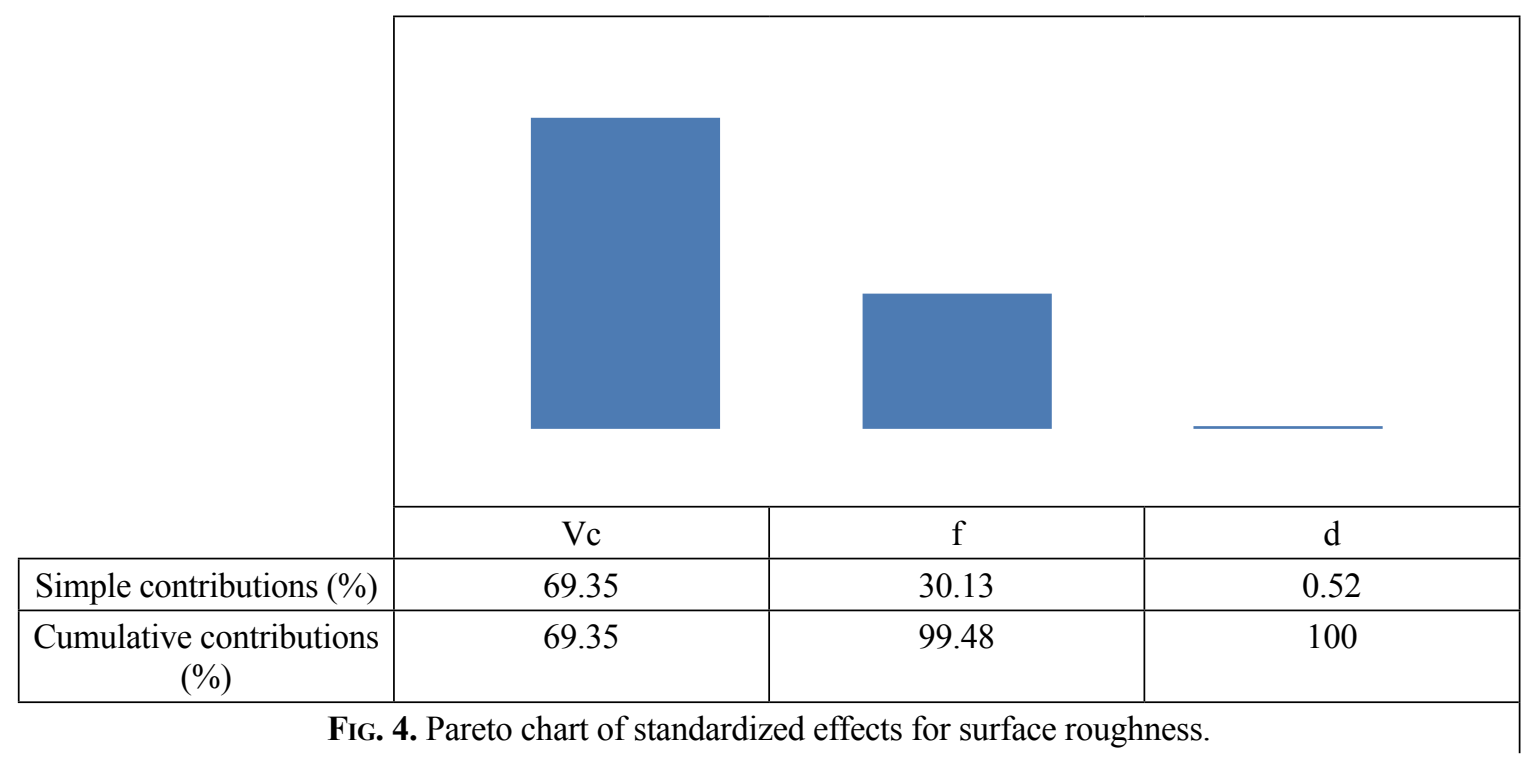

The regression analysis of the input parameters for predicting surface roughness is expressed in equation (1).

$$
\begin{aligned}
& \mathrm{Ra}=192,7444 * \mathrm{Vc}^{-0,7665 * \mathrm{f}^{0,4322} * \mathrm{~d}^{0,1024}} \\
& \mathrm{R}^{2}=0.9526 \\
& \mathrm{R}_{\text {adj }}^{2}=0.9424 \\
& \mathrm{~S}=0.1112
\end{aligned}
$$

Values for $\mathrm{R}^{2}$ and $\mathrm{R}^{2}$ adj are above $90 \%$, indicating that the obtained model fit is on the higher side of the acceptable limit. Finally, the low value for the standard deviation (S) indicates that this expression is adjusted to the experimental data [15].

Figure 5 depicts the normal probability plot for the model; it reveals that the residuals fall in a straight line, implying that the errors are distributed normally, and show that the dependability of the expression is completely proven [12]. 


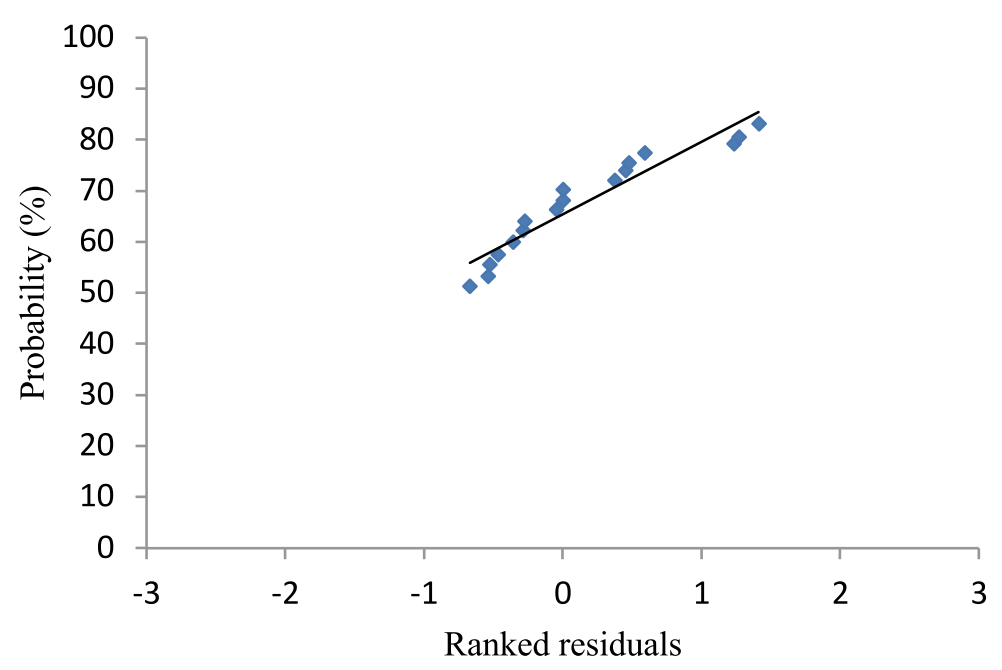

Fig. 5. Normal probability plot for the mathematical equation (1).

\section{Conclusions}

For the range investigated, we can conclude that surface roughness increases when depth of cut $(d)$ and feed rate $(f)$ increase, while decreases with higher cutting speeds $\left(V_{c}\right)$. Furthermore, cutting speed contributes $69.35 \%$, feed rate $30.13 \%$ and depth of cut $0.52 \%$ to surface roughness. Finally, the developed mathematical expression can be used to predict optimum cutting parameters for minimum surface roughness.

\section{REFERENCES}

[1] D. P. Selvaraj, and P. Chandramohan, "Influence of cutting speed, feed rate and bulk texture on the surface finish of nitrogen alloyed duplex stainless steels during dry turning," Engineering, vol. 2 (6), pp. 453-460, 2010. DOI: http://doi.org/10.4236/ eng.2010.26059.

[2] D. P. Selvaraj, and P. Chandramohan, "Optimization of surface roughness of AISI 304 austenitic stainless steel in dry turning operation using Taguchi design method," Journal of Engineering Science and Technology, vol. 5 (3), pp. 293- 301, 2010.

[3] B.A. Khidhir, and B. Mohamed, "Analyzing the effect of cutting parameters on surface roughness and tool wear when machining nickel based Hastelloy - 276," IOP Conf. Series: Materials Science and Engineering, vol. 17, pp. 012043-012053, 2011.DOI: http://doi.org/10.1088/1757-899X/17/1/012043.

[4] C. J. Rao, D. Nageswara, and P. Srihari, "Influence of cutting parameters on cutting force and surface finish in turning operation," Procedia Engineering, vol. 64, pp. 1405 -1415, 2013. DOI: http://doi.org/10.1016/j. proeng.2013.09.222.

[5] M. Hanief, and M. F. Wani, "Influence of cutting parameters on surface roughness of red brass (C23000) in turning using exponential model," Hidráulica, vol. 3, pp. 55-58, 2015.

[6] P. Deepakkumar, and M. Sadaiah, "Investigations on finish turning of AISI 4340 steel in different cutting environments by CBN insert," International Journal of Engineering Science and Technology, vol. 3 (10), pp. 7690-7706, 2011.

[7] D. Deepak, and B. Rajendra, "Investigations on the surface roughness produced in turning of $\mathrm{AL}$ 6061 (as-cast) by Taguchi method," International Journal of Research in Engineering and Technology, vol. 4 (8), pp. 295-298, Aug. 2015. DOI: http://doi. org/10.15623/ijret.2015.0408051.

[8] C. H. Che-Haron, and A. Jawaid, "The effect of machining on surface integrity of titanium alloy Ti-6\% Al-4\% V," Journal of Materials Processing Technology, vol. 166 (2), pp. 188192, Aug. 2005. DOI: http://doi.org/10.1016/j. jmatprotec.2004.08.012.

[9] A. R. C. Sharman, J. I. Hughes, and K. Ridgway, "An analysis of the residual stresses generated in Inconel 718TM when turning," Journal of Materials Processing Technology, vol. 173 (3), pp. 359-367, Apr. 2006. DOI: http://doi.org/10.1016/j. jmatprotec.2005.12.007.

[10] D.C. Montgomery, Design and analysis of experiments, USA, Wiley, 2012.

[11] H. Sasahara, "The effect on fatigue life of residual stress and surface hardness resulting from different cutting conditions of $0.45 \% \mathrm{C}$ steel," International 
Journal of Machine Tools and Manufacture, vol. 45(2), pp. 131-136, Feb. 2005. DOI: http://doi. org/10.1016/j.ijmachtools.2004.08.002.

[12] D.C. Montgomery, E.A. Peck, and G.G. Vining, Introduction to linear regression analysis, USA, Wiley, 2012.

[13] P. Deepakkumar, and M., Sadaiah, "Investigations on finish turning of AISI 4340 steel in different cutting environments by CBN insert," International Journal of Engineering Science and Technology, vol. 3 (10), pp. 7690-7706, 2011.

[14] J. P. Davim, Surface integrity in machining, England, Springer-Verlag, 2010. DOI: http://doi. org/10.1007/978-1-84882-874-2.

[15] D. Peña, Estadística; modelos y métodos, Spain: Alianza, 2001. 